\title{
Simple, Effective Molecular Strategy for the Design of Fuel Cell Membranes: Combination of Perfluoroalkyl and Sulfonated Phenylene Groups
}

Takashi Mochizuki, ${ }^{\dagger}$ Makoto Uchida, ${ }^{\ddagger}$ and Kenji Miyatake, ${ }^{*}, \S$

${ }^{\dagger}$ Interdisciplinary Graduate School of Medicine and Engineering, ${ }^{\dot{t}}$ Fuel Cell Nanomaterials Center, and ${ }^{\S}$ Clean Energy Research Center,

University of Yamanashi, 4 Takeda, Kofu, Yamanashi 400-8510, Japan

*Corresponding Author

E-mail address: miyatake@yamanashi.ac.jp 


\section{Experimental}

\section{Materials}

Perfluoro-1,6-diiodohexane (TCI), 1-chloro-3-iodobenzene (TCI), copper $(\mathrm{Cu})$ powder (particle size 75 - $150 \mu \mathrm{m}$, Kanto Chemical), dimethylsulfoxide (DMSO) (Kanto Chemical), 1,3-dichlorobenzene (TCI), 1,4-dichlorobenzene $\quad(\mathrm{TCI}), \quad$ 2,2-bipyridine $\quad$ (TCI), bis(1,5-cyclooctadiene)nickel(0) (Ni(COD) $)_{2}$ (Kanto Chemical), N,N-dimethylacetamide (DMAc) (Kanto Chemical), and 30\% oleum (Kanto Chemical) were used as received. Other chemicals were of commercially available grade and used as received. Precursor copolymer, poly(phenylene-ran-perfluorohexylene) (PAF) 1 with copolymer composition of n/m $=0.48$ and o/m $=0.62$ was prepared according to the literature (Scheme 1a). ${ }^{1}$

\section{Sulfonation of $\mathbf{1}$ and membrane preparation}

To a $100 \mathrm{~mL}$ of round-bottomed flask, $1(3.7 \mathrm{mmol}, 2.0 \mathrm{~g})$ and $30 \%$ oleum $(36 \mathrm{~mL})$ were charged. The mixture was stirred at room temperature for $72 \mathrm{~h}$. The resulting brown mixture was poured into a large excess of ice-cold deionized water. The precipitate was washed in deionized water and dried at $80{ }^{\circ} \mathrm{C}$ in vacuum oven overnight to obtain a sulfonated PAF (SPAF) 2 as a brown powder in $77 \%$ yield. A solution of polymer 2 (ca. $0.4 \mathrm{~g}$ ) in DMSO (ca. $11 \mathrm{~mL}$ ) was cast onto a leveled glass plate. Heating the solution at $80{ }^{\circ} \mathrm{C}$ overnight gave a ca. $28 \mu \mathrm{m}$ thick, transparent and bendable membrane. The membrane was treated with $1 \mathrm{M} \mathrm{H}_{2} \mathrm{SO}_{4}$ for $24 \mathrm{~h}$ at room temperature, washed with deionized water several times, and dried at room temperature.

\section{Measurements}

Molecular weight of the oligomers and polymers was measured with gel permeation chromatography (GPC) using a Jasco 875 UV detector and a Jasco 805 UV detector for oligomers and polymers, respectively. The eluent was DMF containing 0.01 M LiBr. A Shodex K-805L column was used for oligomers and polymers. Molecular weight was calibrated with standard polystyrene samples. ${ }^{1} \mathrm{H}$ and ${ }^{19} \mathrm{~F}$ NMR spectra were obtained on a JEOL JNM-ECA 500 using deuterated dimethyl sulfoxide (DMSO- $d_{6}$ ) as a solvent and tetramethylsilane (TMS) as an internal reference. Ion exchange capacity (IEC) of the membranes was measured by back-titration. A piece of the membranes (ca. $20 \mathrm{mg}$ ) was equilibrated in $10 \mathrm{~mL}$ of saturated aqueous $\mathrm{NaCl}$ solution for $12 \mathrm{~h}$. The released $\mathrm{HCl}$ by the ion exchange was titrated with standard $0.01 \mathrm{M}$ aqueous $\mathrm{NaOH}$ solution.

Morphology of the membranes was analyzed by transmission electron microscopy (TEM) and small-angle X-ray scattering (SAXS). For TEM observation, the membrane samples were stained with lead $\left(\mathrm{Pb}^{2+}\right)$ ions by ion exchange of the sulfonic acid groups in $0.5 \mathrm{M}$ lead acetate aqueous solution, rinsed with deionized water, and dried in vacuum oven for $12 \mathrm{~h}$. The stained samples were embedded in epoxy resin, sectioned to $50 \mathrm{~nm}$ thickness, and placed on copper grids. Images were taken using a Hitachi $\mathrm{H}-9500$ at the acceleration voltage of $200 \mathrm{kV}$. SAXS experiments were 
performed using a Rigaku NANO-Viewer equipped with a temperature/humidity controlled chamber. The X-ray wavelength was $\lambda=0.154 \mathrm{~nm}$ and the scattering patterns were collected using a Rigaku high speed $2 \mathrm{D}$ detector PILATUS $100 \mathrm{~K} / \mathrm{R}$. The range of the scattering vector, $\mathrm{q}=4 \pi \sin (\theta / 2) / \lambda$, was from 0.05 to $3 \mathrm{~nm}^{-1}$ (ca. $2-120 \mathrm{~nm}$ ), where $\theta$ is the scattering angle. The temperature was set at $80{ }^{\circ} \mathrm{C}$, while the humidity was controlled from $30 \%$ to $90 \% \mathrm{RH}$ under nitrogen atmosphere. The membranes were equilibrated for at least $2 \mathrm{~h}$ under each $\mathrm{RH}$ condition. Water uptake and proton conductivity of the membranes were measured with a solid electrolyte analyzer system (MSBAD-V-FC, Bel Japan Co.) at $80{ }^{\circ} \mathrm{C}$ with varying humidity from $20 \%$ to $95 \% \mathrm{RH}$ (relative humidity). Dynamic mechanical analysis (DMA) of SPAF membrane $(0.5 \mathrm{~cm} \times 3 \mathrm{~cm})$ was carried out in a chamber at $80{ }^{\circ} \mathrm{C}$ with varying humidity. These properties of the SPAF ionomer membrane was compared with those of the aromatic block copolymer, SPP (Figure S1, IEC $=2.67 \mathrm{meq} \mathrm{g}^{-1}$, ca. $29 \mu \mathrm{m}$ thick, synthesized in-house) ${ }^{2}$ and Nafion NRE211 (IEC $=0.91 \mathrm{meq} \mathrm{g}^{-1}$, ca. $25 \mu \mathrm{m}$ thick, Du Pont).

\section{Preparation of catalyst-coated membranes (CCMs)}

A catalyst paste was prepared by mixing Pt/CB catalyst (TEC10E50E, Tanaka Kikinzoku Kogyo K. K.), Nafion dispersion (IEC $=0.95-1.03 \mathrm{meq} \mathrm{g}^{-1}$, D-521, Du Pont), deionized water and ethanol by ball milling for $30 \mathrm{~min}$. The mass ratio of Nafion ionomer to the carbon support (I/C) was adjusted to 0.7. The CCMs were dried at $60{ }^{\circ} \mathrm{C}$ for $6 \mathrm{~h}$ and hot-pressed at $140{ }^{\circ} \mathrm{C}$ and $1.0 \mathrm{MPa}$ for 3 min. The geometric area and the Pt loading amount of the catalyst layer (CL) were $29.2 \mathrm{~cm}^{2}$ and 0.50 $\mathrm{mg} \mathrm{cm}{ }^{-2}$, respectively. The catalyst-coated membranes (CCMs) were prepared with spraying the catalyst paste on both sides of the three ionomer membranes (NRE211, SPP, and SPAF) by pulse swirl spray (PSS) technique. The CCMs were sandwiched by two gas diffusion layers (GDL, 25BCH, SGL Carbon Group Co., Ltd.) and mounted into a Japan Automobile Research Institute (JARI) standard single cell, which has serpentine flow channels on both the anode and the cathode sides. The cell compression was 1.0 MPa. The cells using the NRE211, SPP, and SPAF are denoted as the NRE211-cell, SPP-cell, and SPAF-cell, respectively.

\section{Fuel cell operation}

The electrochemically active surface area (ECSA) of the Pt catalyst at the cathode was estimated by cyclic voltammetry at $80{ }^{\circ} \mathrm{C}$ at $30 \%, 53 \%, 80 \%$, and $100 \% \mathrm{RH}$ using a potentiostat (PGST30 Autolab System, Eco-Chemie). Prior to the cyclic voltammogram measurements, hydrogen (100 $\mathrm{mL}$ $\left.\min ^{-1}\right)$ and nitrogen $\left(150 \mathrm{~mL} \mathrm{~min}^{-1}\right)$ were supplied to the anode and the cathode, respectively. Before the potential sweep, the cathode potential was maintained at $0.07 \mathrm{~V}$ for $3 \mathrm{~s}$. Then, the nitrogen flow was stopped, and the potential was swept from 0.07 to $1.0 \mathrm{~V}$ at a sweep rate of $20 \mathrm{mV} \mathrm{s}^{-1}$. The ECSA values were calculated from the hydrogen adsorption charge in the negative-going potential scan, referred to $\Delta \mathrm{Q}_{\mathrm{H}}{ }^{0}=0.21 \mathrm{mC} \mathrm{cm}^{-2}$, adopted conventionally for clean polycrystalline platinum. ${ }^{3}$ Linear sweep voltammetry (LSV) was measured to evaluate the permeability of hydrogen gas from the 
anode to the cathode through the ionomer membranes. LSV measurement was carried out at $80{ }^{\circ} \mathrm{C}$ at $30,53,80$, and $100 \% \mathrm{RH}$. Prior to the LSV measurements, hydrogen $\left(100 \mathrm{~mL} \mathrm{~min}^{-1}\right)$ and nitrogen $\left(150 \mathrm{~mL} \mathrm{~min}^{-1}\right)$ were supplied to the anode and the cathode, respectively. The cathode potential was swept from 0.15 to $0.6 \mathrm{~V}$ at a sweep rate of $0.5 \mathrm{mV} \mathrm{s}^{-1}$.

To evaluate the cell performance, the polarization curves were measured at $80{ }^{\circ} \mathrm{C}$ and $30 \%, 53 \%$, $80 \%$, and $100 \%$ RH. Pure hydrogen and air were supplied to the anode and the cathode, respectively. The gas utilizations at the anode and the cathode were $70 \%$ and $40 \%$, respectively. The high frequency resistance (HFR) of the cell was measured with an AC milliohmmeter (Model 3356 Tsuruga Electric Corporation) at $1.0 \mathrm{kHz}$. The open circuit voltage (OCV) hold test was carried out under at $80{ }^{\circ} \mathrm{C}$ and $30 \% \mathrm{RH}$. Pure hydrogen and air at a gas flow rate of $100 \mathrm{~mL} \mathrm{~min}^{-1}$ were supplied to the anode and the cathode, respectively. The OCV hold test was continued for $1000 \mathrm{~h}$.

\section{References}

(1) Ono, H.; Miyake, J.; Shimada, S.; Uchida, M.; Miyatake, K. Anion Exchange Membranes Composed of Perfluoroalkylene Chains and Ammonium-Functionalized Oligophenylenes. $J$. Mater. Chem. A 2015, 3, 21779-21788.

(2) Miyake, J.; Mochizuki, T.; Miyatake, K. Effect of the Hydrophilic Component in Aromatic Ionomers: Simple Structure Provides Improved Properties as Fuel Cell Membranes. ACS Macro Lett. 2015, 4, 750-754.

(3) Carter, R. N.; Brady, B. K.; Subramanian, K.; Tighe, T.; Gasteiger, H. A. Spatially Resolved Electrode Diagnostic Technique for Fuel Cell Applications. ECS Transactions 2007, 11, 423-433. 
Table S1 Molecular weight and ion exchange capacity (IEC) of the PAF and SPAF copolymers.

\begin{tabular}{cccccc}
\hline & $M_{\mathrm{n}}{ }^{\mathrm{a}}(\mathrm{kDa})$ & $M_{\mathrm{w}}{ }^{\mathrm{a}}(\mathrm{kDa})$ & $\mathrm{IEC}^{\mathrm{b}}\left(\mathrm{meq} \mathrm{g}^{-1}\right)$ & $\mathrm{IEC}^{\mathrm{c}}\left(\mathrm{meq} \mathrm{g}^{-1}\right)$ & $\mathrm{DS}^{\mathrm{d}}$ \\
\hline PAF & 18.1 & 85.9 & - & - & - \\
$\mathrm{SPAF}$ & 96.1 & 856 & 3.95 & 1.59 & 0.32 \\
\hline
\end{tabular}

${ }^{\mathrm{a}}$ Determined by GPC analyses (calibrated with standard polystyrene samples). ${ }^{\mathrm{b}}$ Calculated from the feed comonomer ratio and $100 \%$ degree of sulfonation per phenylene group (one sulfonic acid per phenylene ring). ${ }^{\mathrm{c}}$ Determined by the titrated IEC value. ${ }^{\mathrm{d}}$ Degree of sulfonation; Number of sulfonic acid per phenylene.

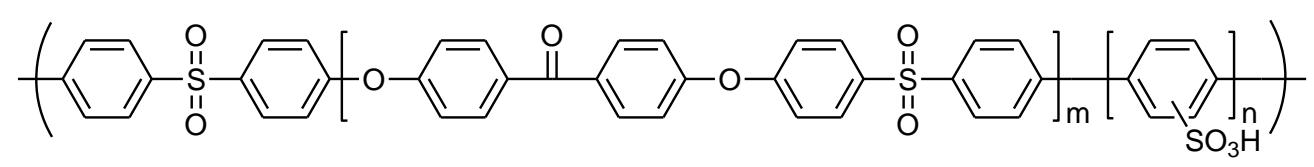

Figure S1. Molecular structure of the SPP copolymer.

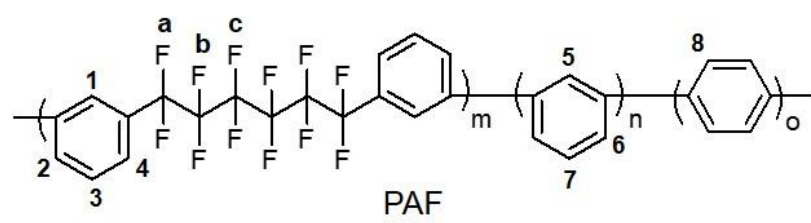

(a)

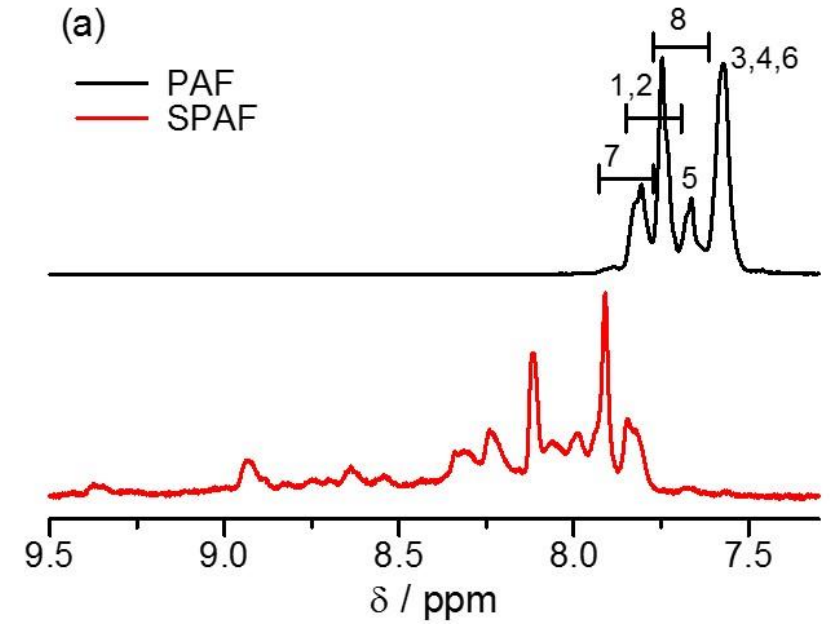

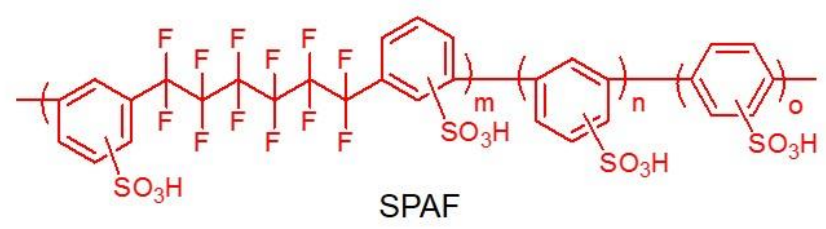

(b)

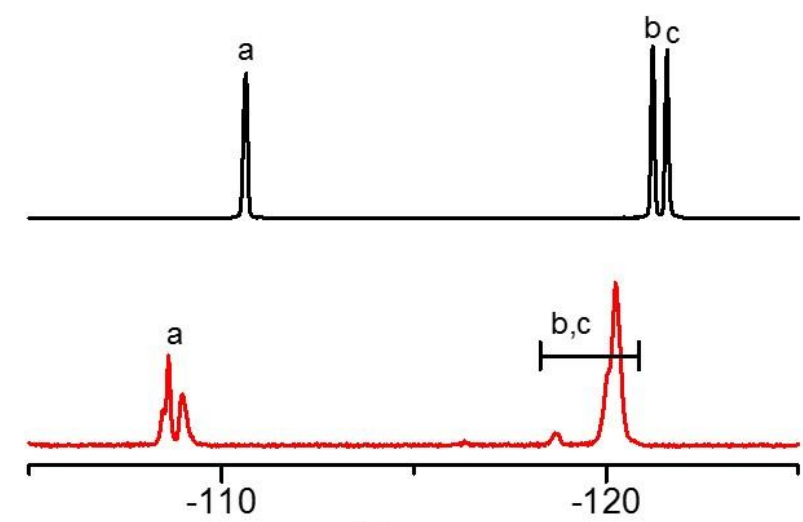

$\delta / \mathrm{ppm}$

Figure S2. (a) ${ }^{1} \mathrm{H}$ and (b) ${ }^{19} \mathrm{~F}$ NMR spectra of the PAF and SPAF copolymers. 


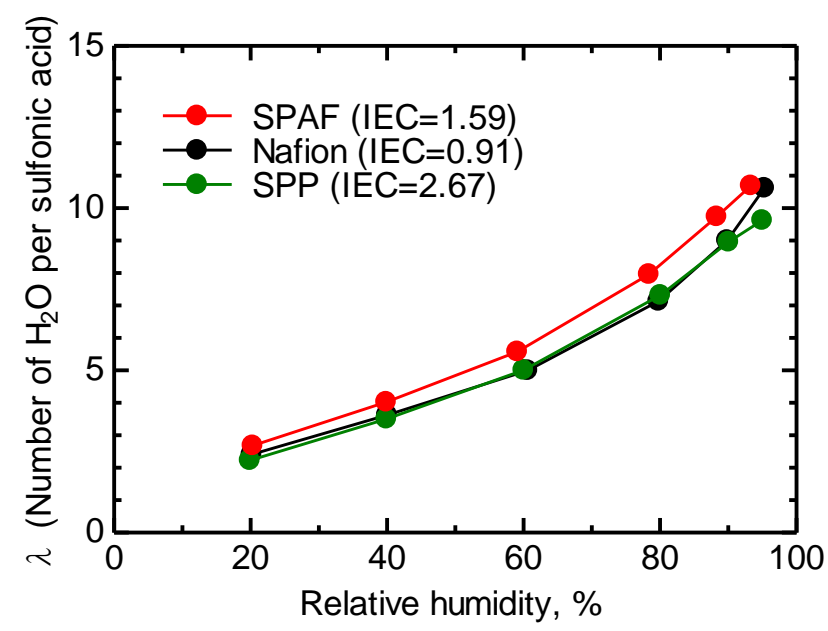

Figure S3. Number of absorbed water molecules per sulfonic acid group $(\lambda)$ of the ionomer membranes as a function of relative humidity at $80^{\circ} \mathrm{C}$.

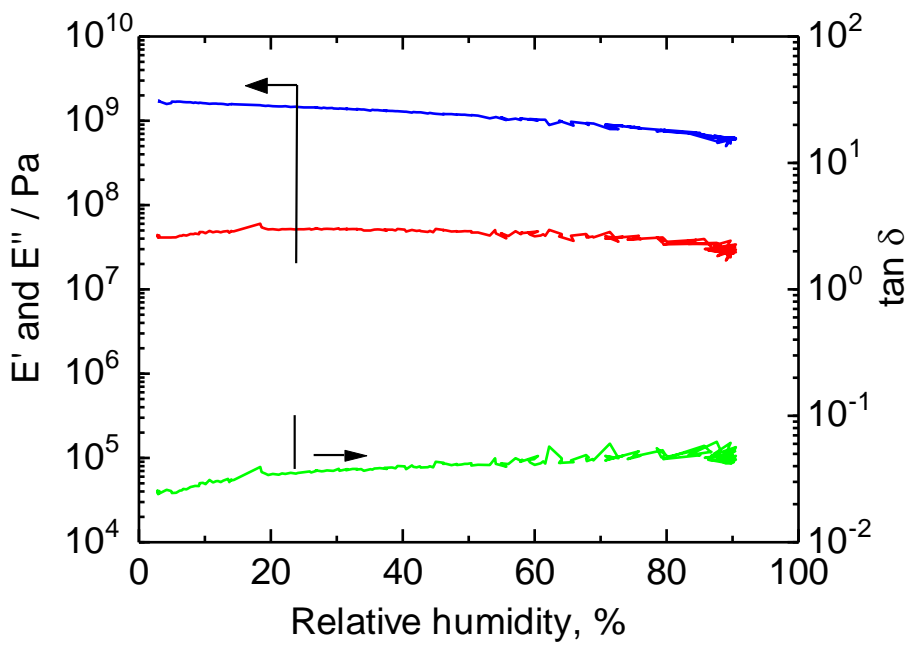

Figure S4. Storage moduli $\left(E^{\prime}\right)$, loss moduli $\left(E^{\prime \prime}\right)$, and $\tan \delta\left(=E^{\prime \prime} / E^{\prime}\right)$ curves of SPAF membrane as a function of relative humidity at $80{ }^{\circ} \mathrm{C}$. 


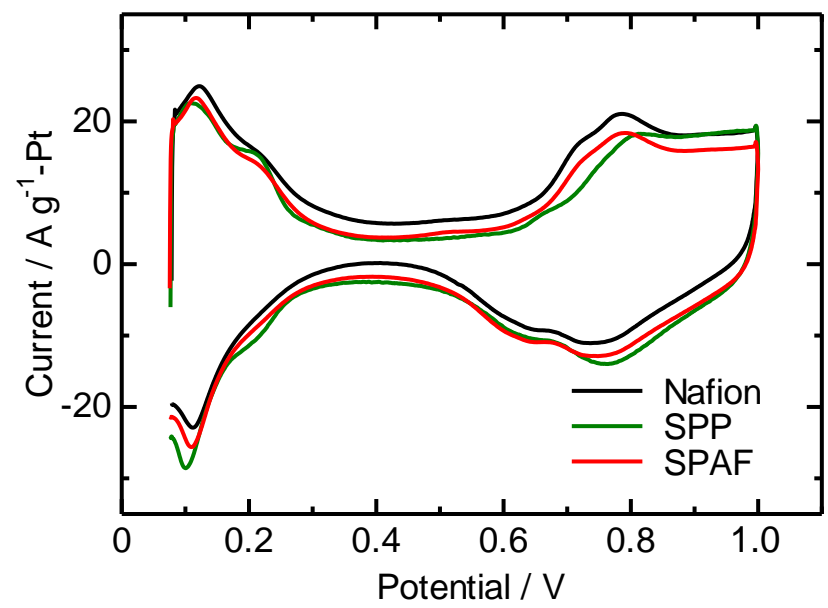

Figure S5. Cyclic voltammograms of the Nafion-, SPP-, and SPAF-cells at $80{ }^{\circ} \mathrm{C}$ and $100 \% \mathrm{RH}$.

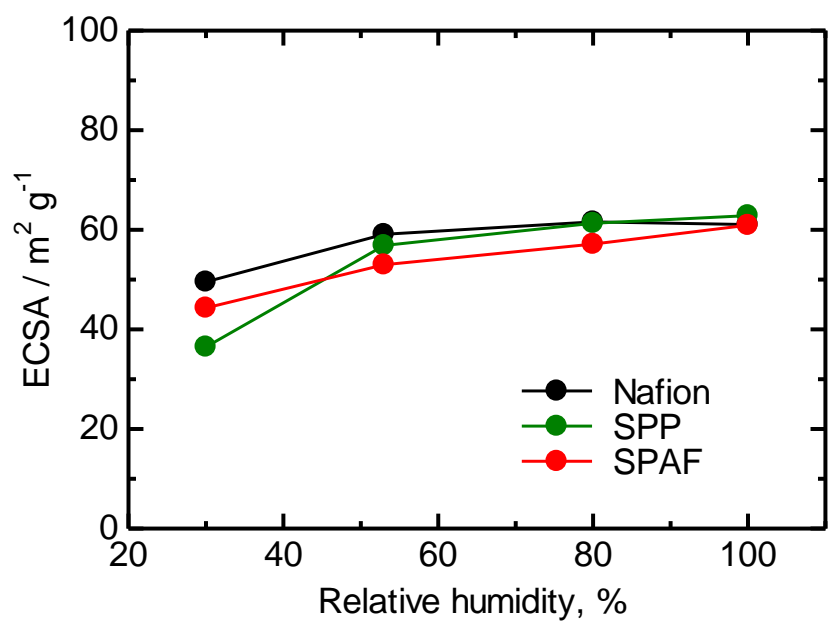

Figure S6. Electrochemically active surface area (ECSA) of the Nafion-, SPP-, SPAF-cells at $80{ }^{\circ} \mathrm{C}$ as a function of relative humidity. 

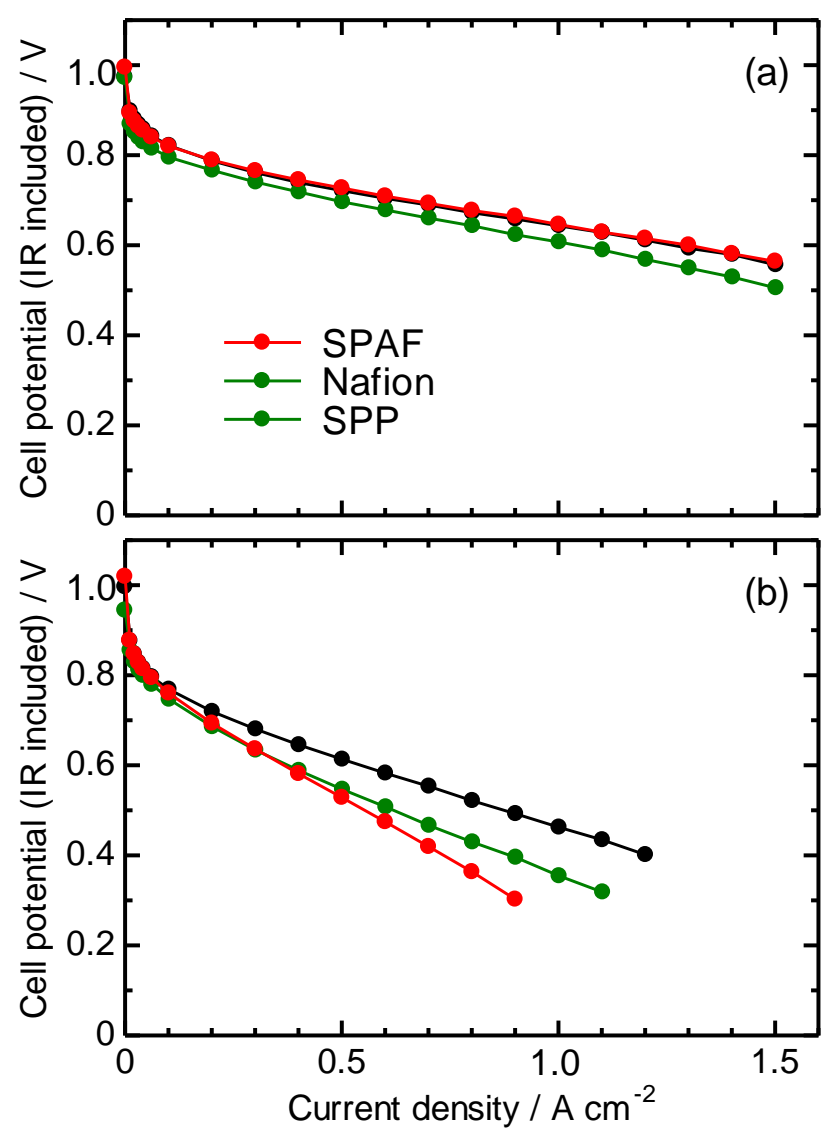

Figure S7. IR-included polarization curves of the Nafion-, SPP-, and SPAF-cells at $80{ }^{\circ} \mathrm{C}$ and (a) $100 \%$, (b) $30 \%$ RH.

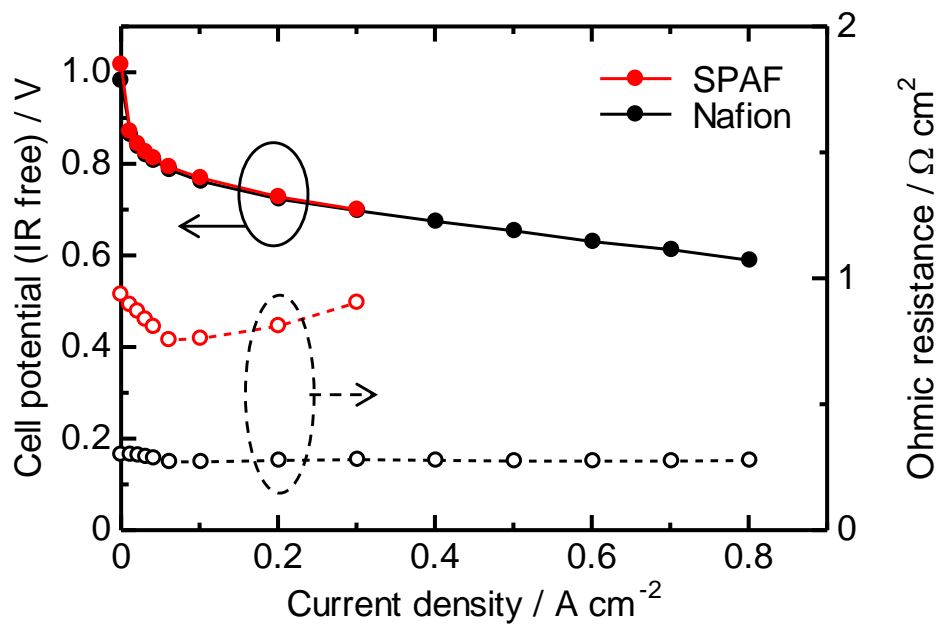

Figure S8. IR-corrected polarization curves of the Nafion- and SPAF-cells at $100{ }^{\circ} \mathrm{C}$ and $30 \% \mathrm{RH}$. 


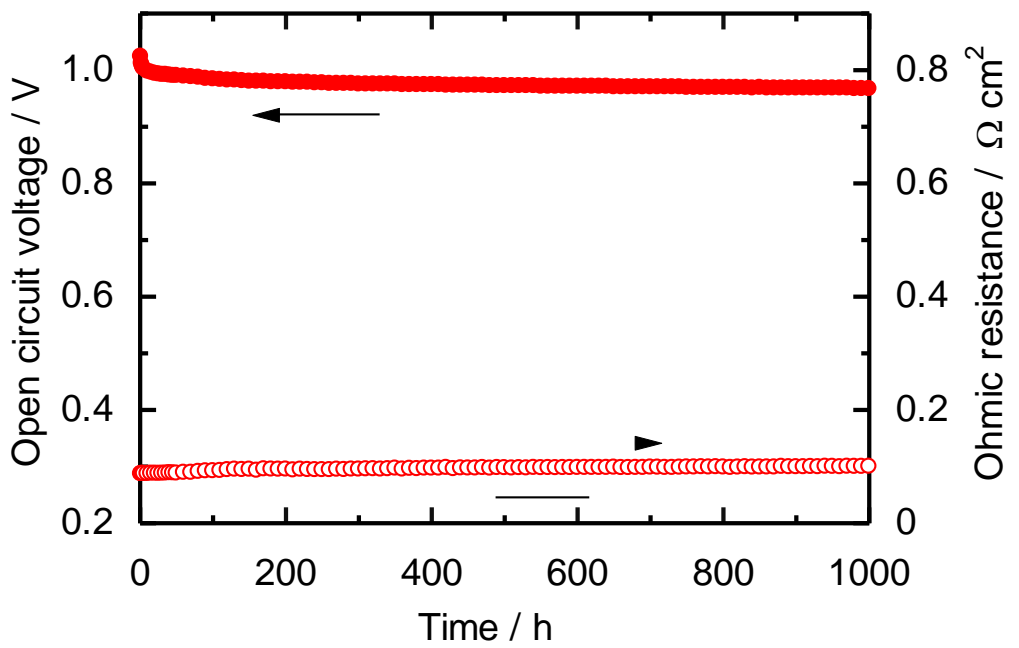

Figure S9. OCV hold test of SPAF membrane at $80{ }^{\circ} \mathrm{C}$ and $30 \% \mathrm{RH}$. 